\title{
Article
}

\section{'The brede of good \& strong Horsis': zooarchaeological evidence for size change in horses from early modern London}

Thomas, Richard, Holmes, Matilda, Morris, James and Abrehart, Emily

Available at http://clok.uclan.ac.uk/24437/

Thomas, Richard, Holmes, Matilda, Morris, James ORCID: 0000-0002-5756-

0362 and Abrehart, Emily (2018) 'The brede of good \& strong Horsis': zooarchaeological evidence for size change in horses from early modern London. Post-Medieval Archaeology, 52 (2). pp. 224-238. ISSN 0079-4236

It is advisable to refer to the publisher's version if you intend to cite from the work. http://dx.doi.org/10.1080/00794236.2018.1515400

For more information about UCLan's research in this area go to http://www.uclan.ac.uk/researchgroups/ and search for <name of research Group>.

For information about Research generally at UCLan please go to http://www.uclan.ac.uk/research/

All outputs in CLoK are protected by Intellectual Property Rights law, including Copyright law. Copyright, IPR and Moral Rights for the works on this site are retained by the individual authors and/or other copyright owners. Terms and conditions for use of this material are defined in the policies page. 


\section{'The brede of good \& strong Horsis': zooarchaeological evidence for size change in horses from early modern London

\author{
By RICHARD THOMAS, MATILDA HOLMES, JAMES MORRIS AND EMILY ABREHART
}

SUMMARY: Almost 200 horse bone measurements from 38 sites excavated across the city of London, dating to the period AD 1220-1900 were analysed. Results identified three main phases of size change: a reduction in size in the mid 14th to 15th century, and size increases in the mid 15th to 16th century and the 17th century. The decline in size testifies to the disruption of horse breeding in the wake of the Black Death, whilst the increases reflect purposeful attempts to increase the size of horses in England through a combination of regulated breeding and the importation of new bloodlines.

\section{INTRODUCTION}

In 2013, Thomas et al. published the analysis of 8000 individual cattle, sheep, pig and chicken bone measurements from 105 sites excavated in London dating to the period AD 1220-1900. Multiple episodes of size increase were identified, although the speed and timing varied by species. The earliest evidence for size change in cattle and sheep was observed in the early 14 th century. This was interpreted as potential evidence for the restocking of livestock populations following major outbreaks of animal disease in the first half of that century. Later increases in the size of all livestock were linked to altered agricultural practices and social pressures following the Black Death (AD 1348-50), status seeking by landowners and the increasing commercialization of animal farming to feed an expanding urban population. In this companion article, we present the analysis of horse bone measurements across the same period.

While zooarchaeologists have long been interested in charting size and shape change in cattle, sheep and pig bones recovered from medieval and early modern sites in England, ${ }^{1}$ far less attention has
1. to determine whether the directed breeding of horses occurred in this period; 
2. to evaluate the social and economic context that precipitated identified changes;

3. to compare and contrast the trajectory of size change in horses with other domesticated livestock.

London is a useful context in which to understand medieval and early modern horse breeding more broadly, not least because of the excellent zooarchaeological record for the city. Although it is difficult to estimate the numbers of horses in medieval and early modern London, ${ }^{7}$ a variety of different types of horses would have been a familiar sight on the streets. ${ }^{8}$ A horse fair was held every Friday at Smithfield from the 12th century until the 19th century. ${ }^{9}$ Thus, many of these horses would have been bred from across England and possibly also abroad.

\section{MATERIALS AND METHODS}

Since the early 1990s Museum of London Archaeology (MOLA; formerly Museum of London Specialist Services and Museum of London Archaeological Service) has systematically recorded zooarchaeological data from developer-funded excavations in and around the city in a single database. Included amongst this data-set is a large archive of animal bone measurements, recorded using the standard set forth by von den Driesch, ${ }^{10}$ the potential of which is only just being realized. ${ }^{11}$

For this study, almost 200 horse bone measurements from 38 multi-period sites with contexts dating AD 1220-1900 (Fig. 1, Table 1) were analysed. To facilitate the identification of temporal trends and maximize the sample size, bone measurements were placed into eight overlapping phases (Table 2). Broadly and insecurely dated assemblages (indicated by the presence of residual pottery) were excluded from the analysis, under the presumption that bones and pots shared comparable taphonomic pathways. Despite these precautions, the deeply stratified and complex nature of London's archaeology means it is impossible for any study to guarantee that no bones were redeposited. However, the use of only securely dated undisturbed contexts combined with a large sample size should limit the effects of redeposition.

Only skeletally mature horse bones were included and bones with late-fusing epiphyses were preferred to minimize the effect of post-fusion growth, which has been documented in other species. ${ }^{12}$ Dimensions in only two anatomical planes could be collated (lengths and widths); unfortunately, it remains the case that few zooarchaeologists take and report depth measurements on horse bones, despite their inclusion within the standard guidelines for bone measurements. ${ }^{13}$ The focus on disarticulated horse bones meant that sex could not be assessed.
The metrical data were first analysed using withers height calculations. ${ }^{14}$ One of the weaknesses of these calculations is that only bones providing greatest length measurements can be included, thus reducing the size and the statistical validity of the samples. The generated formulae also reflect the conformation of the breeds/types of horses used in the study, and values will be less accurate when determining withers in breeds/types with different relative bone lengths. Moreover, withers calculations only provide information about one dimension (height). For this reason, log-scaling was employed to increase the corpus of usable data and to explore other bodily dimensions. This technique involves converting all measurements to base-10 logarithms by relativizing each against a standard; ${ }^{15}$ for this study, the standard comprised an 18th-century horse from Nicholas Street Mews, Chester, UK (Table 3), sexed as female based on the morphology of the pelvis and aged $10-14$ years. ${ }^{16} \mathrm{~A}$ positive value indicates that the archaeological specimen is larger than the standard, a negative value that it is smaller, while zero indicates that the standard and archaeological specimens are identically sized. No positively identified donkeys (Equus asinus) or horse-donkey hybrids (mules and hinnies) are included; but the possibility exists that some have been misidentified as horse (Equusc $\bigcirc$ ), given their morphological similarity. ${ }^{17} \mathrm{Tl} /$ istical significance of temporal differences in bone size was tested using the nonparametric Mann-Whitney pairwise test, in recognition of the fact that sample sizes were unequal and the data for most phases were not normally distributed.

\section{RESULTS}

Examination of withers height calculation (Fig. 2) reveals that in the first phase under consideration (1220-1350), the horses were relatively small: the average stature approached 14 hands high (hh) $(1.42 \mathrm{~m})$. Thus, it can be concluded that most horses in London were ponies by modern standards (i.e. less than $14.2 \mathrm{hh}^{18}$ ). That said, there is a surprisingly wide range in horse size; whilst the average was very small, the maximum height in this phase was just over $16 \mathrm{hh}(1.63 \mathrm{~m})$, the average size of a contemporary thoroughbred. ${ }^{19}$

A reduction in average horse size occurred in the later 14th to 15th century: the average horse decreased to an average height of less than 13hh $(1.32 \mathrm{~m})$, and a maximum height of less than $14 \mathrm{hh}$. The first notable increase in stature took place between the mid 15th and 16th centuries, when the mean horse size increased to over $14 \mathrm{hh}$. A second phase of size increase occurred in the 17th century, with the minimum size increasing significantly to almost $14 \mathrm{hh}$ and the average reaching over $15 \mathrm{hh}$. 


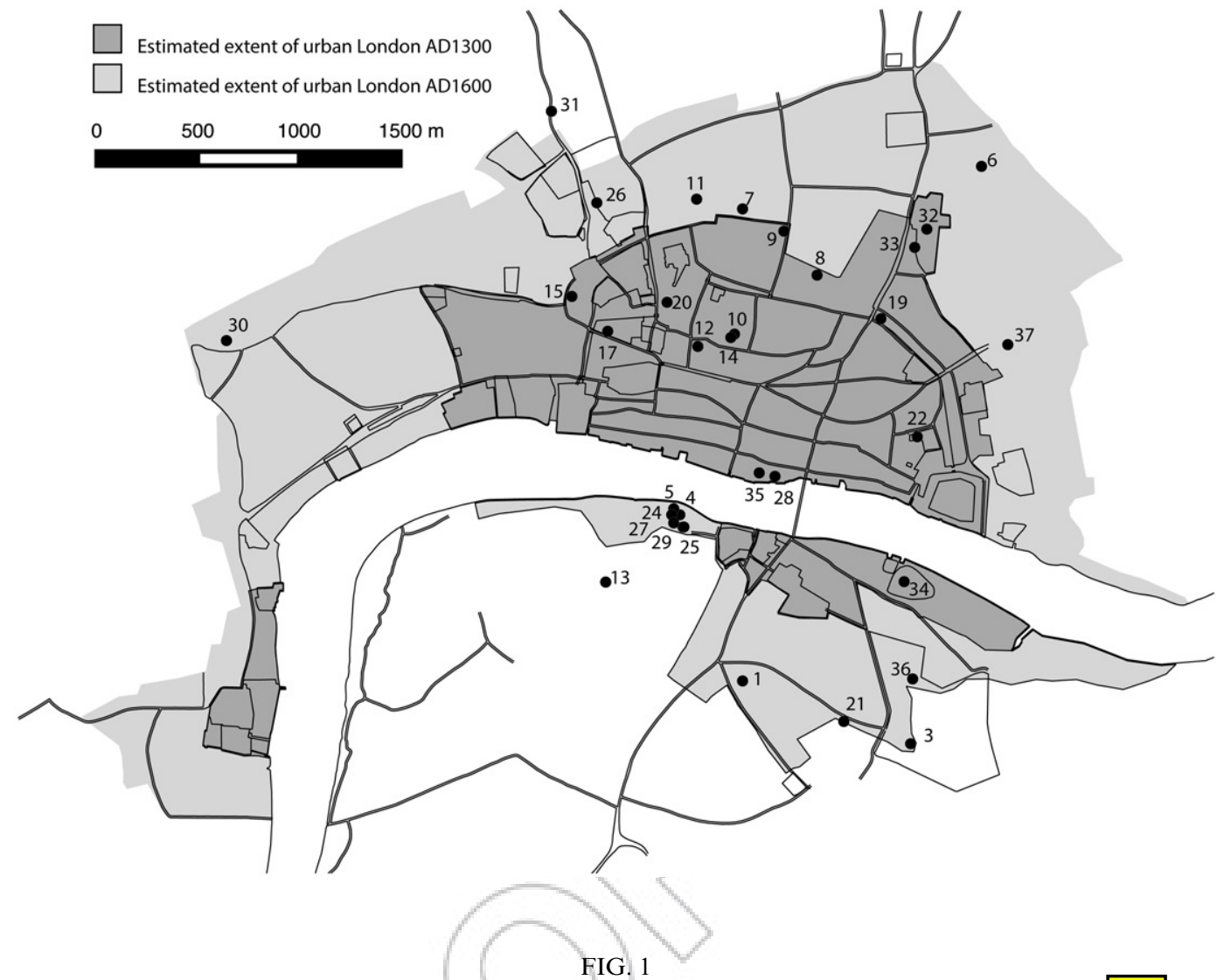

Location of sites within the central London area included in this analysis. Numbers relate to sites in Table 16, 18, 23 and 38 are located within the greater London area and not shown.

TABLE 2

Number of length and width measurements by phase

\begin{tabular}{lccc}
\hline Phase & Dates & Lengths & Widths \\
\hline A & $1220-1350$ & 13 & 14 \\
B & $1340-1500$ & 17 & 18 \\
C & $1450-1600$ & 5 & 11 \\
D & $1550-1650$ & 46 & 42 \\
E & $1600-1700$ & 6 & 12 \\
F & $1650-1725$ & 6 & 8 \\
G & $1700-1800$ & 18 & 17 \\
H & $1800-1900$ & 6 & 3 \\
\hline
\end{tabular}

This increase is statistically significant (Table 4). The period $1650-1725$ shows a slight decrease in average size, although a greater range, and there is no size change in the 18 th century. Only one greatest length measurement derived from a 19th-century horse.
The results from the log-scaling analysic are consistent with the withers height data (Fig. $3-$ erall, the analysis of length measurements 1 .....s an increase in mean size from the mid 14th to the 19th century. The reduction in size in the mid 14th to the 15 th century observed in withers heights calculations is reflected in the log-scaled measurements, as are the increases in size in the mid 15th to 16th century and the 17th century. Changes between consecutive phases lack statistical significance, but the increases in size are confirmed when later phases are compared (Table 5).

Breadth measurements are more variable (Fig. 3) and could evidence change in the shape of horses, or changing ratios of male and female horses. While there is a gradual upward trajectory from the mid 13th century, the horses in the mid 16th to mid 17th century, and again in the mid 17 th to early 18 th century, appear to have been relatively more gracile. A reduction in overall horse size is again indicated in the later 14th-15th century, followed by a rebound in the late 15 th-16th century. 
TABLE 3

Standard measurements (in $\mathrm{cm}$ ) used in the log-scaling analysis, derived from an 18th-century horse from Nicholas Street Mews, Chester, UK (Gordon 2015). Measurement codes follow von den Driesch (1976)

\begin{tabular}{|c|c|c|c|c|c|c|}
\hline \multirow[b]{2}{*}{ Bone } & \multicolumn{2}{|c|}{ Length } & \multicolumn{2}{|c|}{ Breadth } & \multicolumn{2}{|c|}{ Depth } \\
\hline & Measurement & Value & Measurement & Value & Measurement & Value \\
\hline 1st Phalanx & GL & 9.3 & $\mathrm{Bp}$ & 6.5 & $\mathrm{Dp}$ & 4.4 \\
\hline 2nd Phalanx & GL & 5.7 & $\mathrm{Bp}$ & 6.1 & $\mathrm{Dp}$ & 3.9 \\
\hline Astragalus & $\mathrm{GH}$ & 6.4 & GB & 7.1 & - & \\
\hline Calcaneum & GL & 12.6 & - & - & - & \\
\hline Femur & GL & 46.5 & $\mathrm{Bd}$ & 10.8 & DC & 7.1 \\
\hline Humerus & GL & 35.0 & $\mathrm{Bd}$ & 9.7 & & \\
\hline Metacarpal & $\mathrm{Ll}$ & 24.3 & $\mathrm{Bd}$ & 5.6 & D & 2.9 \\
\hline Metatarsal & $\mathrm{Ll}$ & 27.9 & SD & 3.7 & & \\
\hline Radius & $\mathrm{Ll}$ & 32.4 & SD & 4.4 & & \\
\hline Tibia & $\mathrm{L} 1$ & 37.0 & $\mathrm{Bd}$ & 9.0 & & \\
\hline
\end{tabular}

\section{DISCUSSION}

The fact that the medieval horses from London were, on average, comparable to the size of ponies (i.e. less than 14hh) is consistent with what we know about horse size in the period from bits, horseshoes, art-historical evidence and osteological evidence from England. ${ }^{20}$

The diversity of sizes testifies to the fact that different types of horses existed - and presumably served distinct functions. Certainly, a strong correlation exists between desired function and size/body type in modern horses and skeletal conformation is a primary determinant of body type. ${ }^{21}$ A 12 th-century account of the weekly horse market at Smithfield, London, describes a full range of different horse types for sale, including warhorses, riding horses, pack horses and plough horses. ${ }^{22}$ Unfortunately, determining whether individual horses were used for hunting, riding, agriculture, trade or the military, or for a combination of activities, is exceedingly difficult on osteological grounds, and this difficulty is increased when the material is single bones rather than complete skeletons from burials.

One of the tallest horses in this study was dated to the 13 th to the mid 14 th century at over $16 \mathrm{hh}$, and is represented by a metatarsal and tibia recovered from fills of the north-west city ditch at Bishopgate, alongside remains from smaller horses. This could provide potential evidence of a 'Great Horse'. These specially bred destriers (entire males) attest to considerable investment in horse breeding for warfare by the Plantagenet kings. ${ }^{23}$ Some estimates place these war horses as tall as 17 or $18 \mathrm{hh}$-although it has been questioned whether they were taller than 15 or $16 \mathrm{hh} .{ }^{24}$ The valuations of destriers between 1295 and 1302 suggest a range of sizes. ${ }^{25}$

Evidence from London demonstrates an increase in the length, width and weight of horseshoes in the 13 th century. ${ }^{26}$ While not all horses would have been shod, the practice became increasingly common following the Norman Conquest, ${ }^{27}$ perhaps linked to the increase use of horses as working animals. Clark suggests three explanations for this shift: ${ }^{28}$

- a greater proportion of larger horses;

- a greater proportion of breeds with larger feet;

- a fashion for full-fitting shoes.

Zooarchaeological data are needed from 11thand 12th-century sites from London to test whether an increase in horse size did occur. Nevertheless, it is interesting that the 13th century corresponds to the period when horses were beginning to replace oxen on farms (especially in south-east England), ${ }^{29}$ and the larger horseshoes may testify to the development of larger and stronger horses for this reason.

The decline in mean horse size in the mid 14th to 15 th century runs counter to the trend observed in other livestock in London ${ }^{30}$ and has not been documented previously. A larger data-set is required to confirm the validity of this pattern; however, this phenomenon is potentially consistent with the documented social and economic upheaval of this period. By the 13th and early 14th century, parks, forest, waste and chases were being used extensively by the aristocracy as stud farms for the selective breeding of horses. ${ }^{31}$ After a series of disasters culminating in the Black Death in the mid 14th century, however, aristocratic incomes declined significantly. ${ }^{32}$ Furthermore, there was a significant reduction in land designated forest, ${ }^{33}$ as the aristocracy sought to diversify their income. Changes in the exploitation of other animals kept in these environments corroborate this shift. ${ }^{34}$ Combined, these factors may have reduced aristocratic investment in horse breeding, which was an expensive 


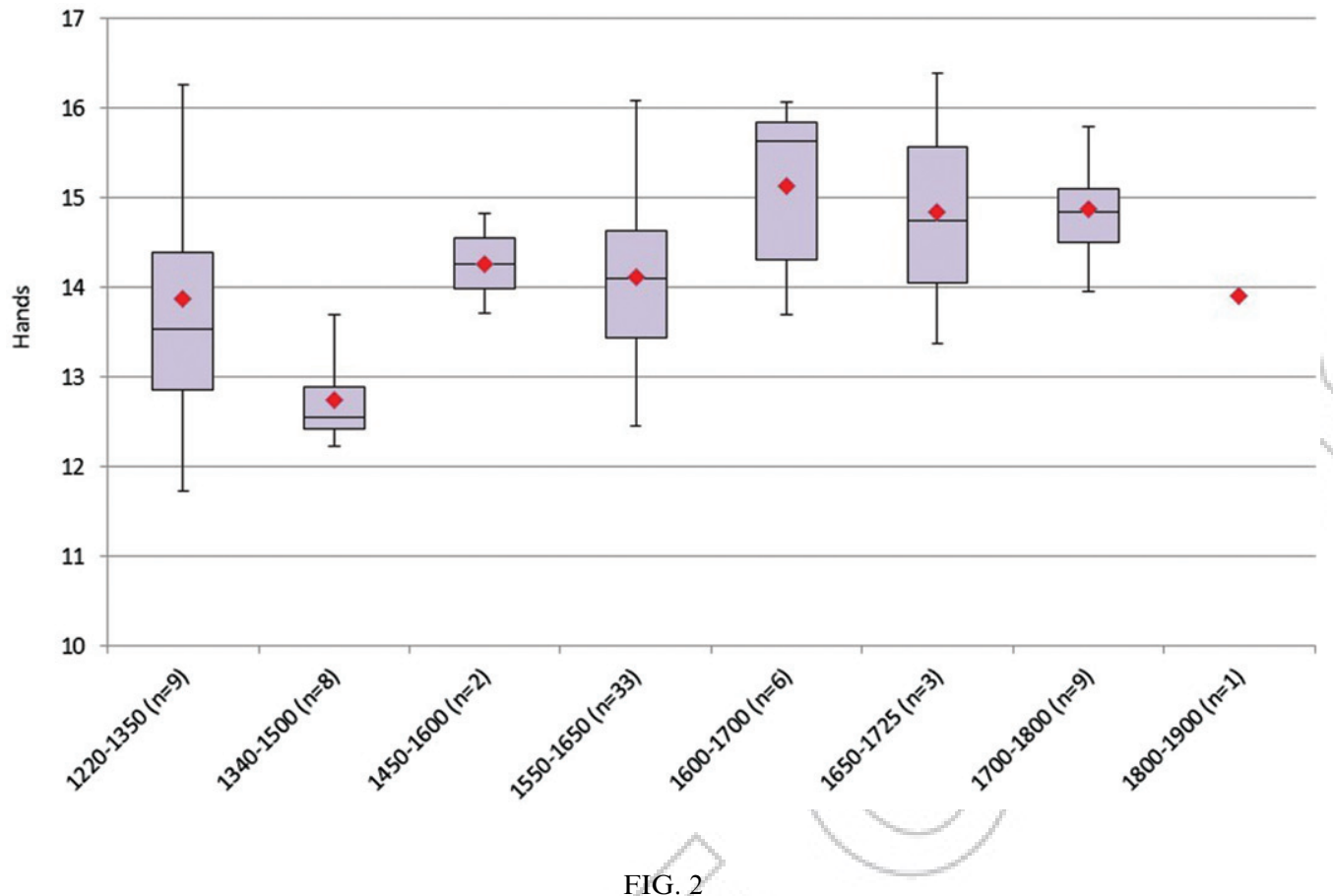

Wither heights of horses in hands from medieval and early modern London (after Kiesewalter 1888). The mean of each data-set is indicated by a red diamond.

business, ${ }^{35}$ and resulted in less discriminating selection of stallions-written sources suggests that careful selection of mares was not practised until the later 16 th century ${ }^{36}$ - and potentially crosses with smaller feral or loosely managed horses. Edwards ${ }^{37}$ has detected a 'noticeable decline in interest displayed by English kings in their studs' in the 14th century, as well as a breakdown in international horse trading. There was certainly a major crash in the number of royal stud accounts in the second half of the 14th century. ${ }^{38}$ Outbreaks of disease may have also been a factor: in 1360 Edward III reduced his studs after 'murrain broke out regularly and indiscriminately'. 39 A related factor that may have contributed to the decline in horse size is the succession of harvest failures throughout the course of the early 14th century. As Gladitz notes, "hay and the expense of winter feeding bore directly on the size and average age of the horse population of each type ${ }^{40}$ If less feed were available, particularly over winter, the horses would be less likely to fulfil their genetic potential. Fertility was also compromised by the practice of not separating brood from working mares: the practice of using mares for ploughing, harrowing and carting certainly appears to have increased in the wake of the Black Death. ${ }^{41}$

By the time of the Tudor accession, the horses of England were considerably diminished in stature and in numbers: the War of the Roses (1485) exacted a particularly heavy toll. ${ }^{42}$ Indeed, a statute of Henry VIII in 1535-36 declared 'the brede of good \& strong Horsis of this Realme is nowe lately dymynyshid altired \& decayed \& farther is lyke to decaye if spedy remedye be not the soner providid in that behalfe'. ${ }^{43}$ When a survey of horses was undertaken in 1539 to service Henry VIII's military campaigns, it was revealed there were no horses of a suitable size and stamina in the south of England and the sto-cks in northern England were also depleted. ${ }^{44}$

Successive laws were issued and accompanied by a 'strong propaganda campaign'45 to reverse this 'decay', which had four broad emphases: ${ }^{46}$

- prohibiting the export of breeding horses (11 Henry VII; 22 Henry VIII; 23 Henry VIII);

- controlling the size of breeding-age mares and stallions amongst the aristocracy (in deer parks) and on common ground (27 Henry VIII; 32 Henry VIII; 33 Henry VIII);

- increasing the number of stallions - over $14 \mathrm{hh}$ held by nobles, although varying in number by rank (33 Henry VIII, 38 Henry VIII);

- destruction of horses that were undersized, infertile and/or unable to work profitably (32 Henry VIII). 
TABLE 4

Probabilities (lower register) and U-values (upper register) of the Mann-Whitney pairwise test of withers height calculations. Highlighted values are statistically significant $(p<0.05)$

\begin{tabular}{lcccccccc}
\hline & $\mathbf{A}$ & $\mathbf{B}$ & $\mathbf{C}$ & $\mathbf{D}$ & $\mathbf{E}$ & $\mathbf{F}$ & $\mathbf{G}$ & $\mathbf{H}$ \\
\hline A & & 15.5 & 6 & 121 & 15 & 7 & 20 & 4 \\
B & 0.0541 & & 0 & 26 & 0 & 2 & 0 & 0 \\
C & 0.5557 & 0.0502 & & 28 & 3 & 3 & 4 & 1 \\
D & 0.4079 & 0.0005 & 0.7491 & & 48 & 33 & 72 & 14 \\
E & 0.1753 & 0.0024 & 0.4047 & 0.0493 & & 8 & 21 & 1 \\
F & 0.2673 & 0.0525 & 0.7728 & 0.3598 & 0.8973 & & 13 & 1 \\
G & 0.0774 & 0.0006 & 0.2888 & 0.0198 & 0.5169 & 1.0000 & & 0.1637 \\
H & 1.0000 & 0.1752 & 0.5403 & 0.8385 & 0.4533 & 1.0000 & \\
\hline
\end{tabular}

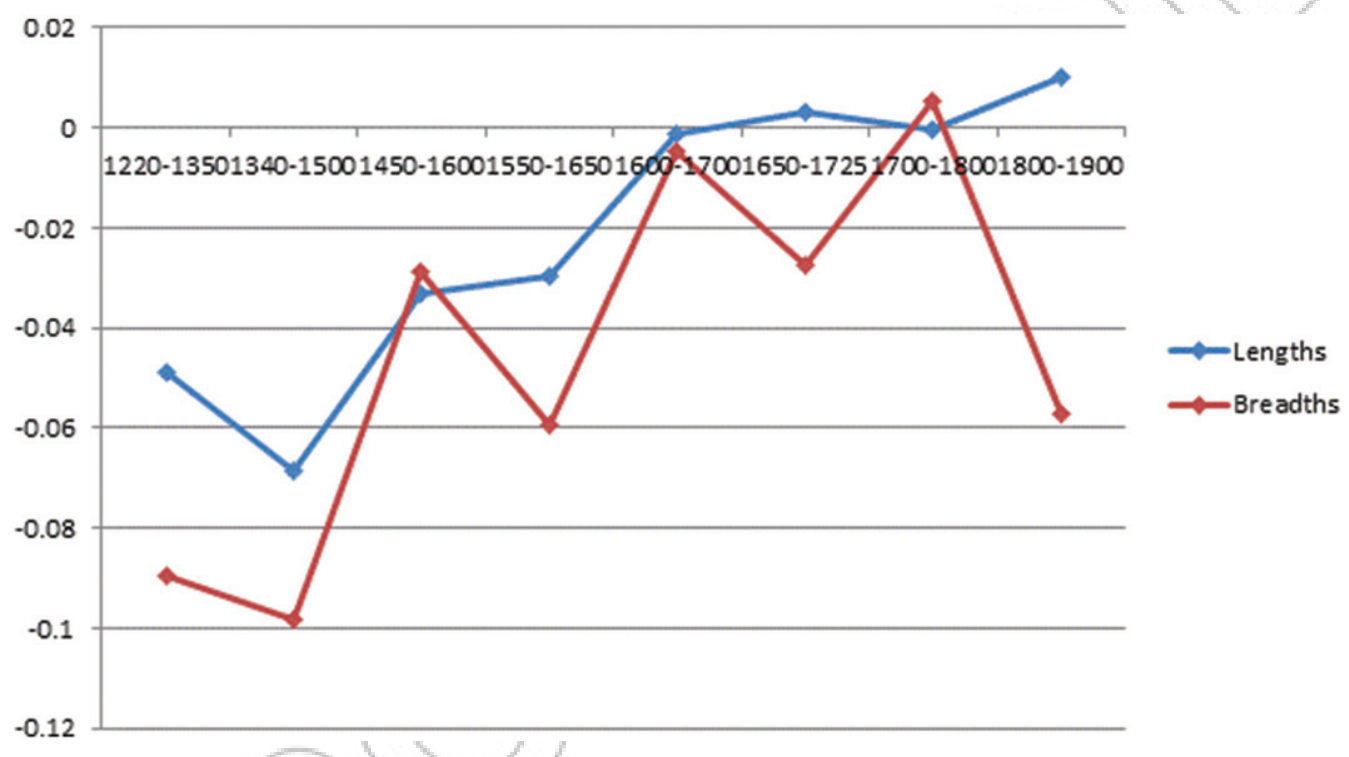

FIG. 3

Log-scaled analysis of horse bone measurements

This legislation remained largely in place for over a century and was doubtless assisted by the concentration of the royal stud in a few specialized centres ${ }^{47}$ and the complementary strategy of importing considerable numbers of 'exotic' horses from Europe and North Africa. Whilst documentary sources attest to the importation of horses for breeding in the 13th and 14 th centuries, ${ }^{48}$ the scale and frequency seems to have increased in the 16th century. A survey of two royal studs in 1576 , for example, reveals a high proportion of mares and stallions with Neapolitan, Spanish, Barbary and Turkish blood. ${ }^{49}$ The virtues of foreign horses were certainly extolled by contemporary writers such as Thomas Blundeville and Gervase Markham. ${ }^{50}$
A special commission 'for the Increase and Breed of Horses' was appointed by Elizabeth in 1580 to reinforce the statutes. ${ }^{51}$ The success of these policies is difficult to establish through the written sources: Henry VIII declared in the preamble to the 'Bill for greate Horses' in 1541-42 that 'ther is begon a good nombre of brede of horses whiche by contynuance is like in shorte tyme muche to encreace'. ${ }^{52}$ However, by 1557 the testimony of a Venetian ambassador was considerably less favourable: 'the island produces a greater number of horses than any other region in Europe; but the horses being weak and of bad wind, fed merely on grass ... they cannot stand much work and they would do much better if they were fed'. ${ }^{53}$ Anecdotes aside, that the embarrassment 
TABLE 5

Probabilities (lower register) and U-values (upper register) of the Mann-Whitney pairwise test of log-scaled length measurements. Highlighted values are statistically significant $(p<0.05)$

\begin{tabular}{lcccccccc}
\hline & $\mathbf{A}$ & $\mathbf{B}$ & $\mathbf{C}$ & $\mathbf{D}$ & $\mathbf{E}$ & $\mathbf{F}$ & $\mathbf{G}$ & $\mathbf{H}$ \\
\hline $\mathrm{A}$ & & 83.5 & 27 & 231 & 16 & 14 & 48 & 14 \\
$\mathrm{~B}$ & 0.2673 & & 25 & 195 & 11 & 7 & 35 & 9 \\
C & 0.6221 & 0.1829 & & 114 & 8 & 9 & 26 & 7 \\
$\mathrm{D}$ & 0.2170 & 0.0025 & 0.9874 & & 77 & 69 & 229.5 & 61.5 \\
$\mathrm{E}$ & 0.0485 & 0.0057 & 0.2353 & 0.0831 & & 16 & 54 & 15 \\
$\mathrm{~F}$ & 0.0317 & 0.0023 & 0.3153 & 0.0498 & 0.8102 & & 49 & 17 \\
G & 0.0061 & 0.0001 & 0.1679 & 0.0060 & 0.9734 & 0.7642 & & 47 \\
H & 0.0317 & 0.0037 & 0.1709 & 0.0295 & 0.6889 & 0.9362 & 0.6648 & \\
\hline
\end{tabular}

TABLE 6

Probabilities (lower register) and U-values (upper register) of the Mann-Whitney pairwise test of log-scaled breadth measurements. Highlighted values are statistically significant $(p<0.05)$

\begin{tabular}{lccccccccc}
\hline & $\mathbf{A}$ & $\mathbf{B}$ & $\mathbf{C}$ & $\mathbf{D}$ & $\mathbf{E}$ & $\mathbf{F}$ & $\mathbf{G}$ & $\mathbf{H}$ \\
\hline $\mathrm{A}$ & & 99 & 22 & 158.5 & 8 & 8 & 4 & 13 \\
$\mathrm{~B}$ & 0.3141 & & 19 & 170 & 1 & 6 & 0 & 10 \\
$\mathrm{C}$ & 0.0028 & 0.0004 & & 148 & 47 & 42 & 50 & 11 \\
$\mathrm{D}$ & 0.0106 & 0.0008 & 0.0704 & & 81 & 84 & 69.5 & 59 \\
$\mathrm{E}$ & 0.0001 & 0.0000 & 0.2549 & 0.0004 & & 28 & 79 & 7 \\
$\mathrm{~F}$ & 0.0012 & 0.0003 & 0.9014 & 0.0271 & 0.1325 & & 31 & 8 \\
$\mathrm{G}$ & 0.0000 & 0.0000 & 0.0431 & 0.0000 & 0.3190 & 0.0334 & & 5 \\
$\mathrm{H}$ & 0.3447 & 0.0973 & 0.4363 & 0.8735 & 0.1296 & 0.4750 & 0.0342 & \\
\hline
\end{tabular}

amongst the nobility and gentry of having sub-standard horses turned down during the muster may have been a significant social pressure. ${ }^{54}$

A suite of non-military drivers may have also stimulated the market demand for the taller horses observed in the zooarchaeological record in the 16th and 17 th centuries, including: ${ }^{55}$

- the growth in trade and industry, which would have increased the need for cart, wagon and pack horses;

- the continued shift away from ploughing with cattle to horses;

- the introduction of coaches and carriages;

- rising standards of living which increased horse use, even amongst the lower classes, and promoted their use as signifiers of status;

- increasing specialized use of horses for sport and equitation amongst the nobility and gentry.

Many of the horses from London may well have fulfilled several of these roles during their lives: for example, Fussell ${ }^{56}$ recounts midland horses that were bought at the age of two or three, worked on farms until they were six, and then sold on for use as London coach horses. Irrespective of the underlying drivers, the zooarchaeological evidence presented here supports the view that progress was made in the breeding of taller horses in the 16th century. The fact that the horses from London were relatively shorter in breadth (Fig. 3), could attest to the presence of lighter morphotypes: a trend identified in the documentary sources. ${ }^{57}$

A second phase of size increase occurred in London in the 17th century. This coincides with a documented increase in the numbers of horses and horse owners: Thirsk ${ }^{58}$ notes that the number of households with horses in the village of Yetminster, Dorset, increased from one-fifth to three-fifths between the 1590s and 1660s. An increased population of horses would have enhanced opportunities for more careful selection of breeding pairs, a process doubtless facilitated by the progressive enclosure of land, which would have reduced opportunities for 'unregulated sexual encounters'. ${ }^{9}$ Certainly, contemporary writers were much more favourable about the quality of horse breeds in England in the 17 th century. ${ }^{60}$
799

800

801

802

803

804

805

806

807

808

809

810

811

812

813

814

815

816

817

818

819

820

821

822 
Continued demand for horses of distinct types facilitated the development of specialized horse breeding and rearing areas. ${ }^{61}$ Daniel Defoe provides some sense of this in 1720 , when he wrote of Leicestershire:

the horses produced here, or rather fed here, are the largest in England, being generally the great black coach horses and dray horses, of which so great a number are continually brought up to London, that one would think so little a spot as this of Leicestershire could not be able to supply them. ${ }^{62}$

The reference to coaching is particularly relevant, since horse-drawn public transport commenced in London in the 17th century alongside private coaches. ${ }^{63}$ The import of foreign horses also continued throughout the 17 th century to 'improve' native stock. ${ }^{64}$ The increased size of the bones could also reflect better nutrition (enabling horses to fulfil their genetic potential); the abundance of early modern print media focusing on horse husbandry, breeding and healthcare is notable. ${ }^{65}$

The average size of horses might be expected to increase in the 18th and 19th centuries, reflecting the development of the thoroughbred racehorse and heavier coach and draught horses. ${ }^{66}$ The fact that such changes are not attested in the zooarchaeological record for London is quite possibly a function of the small size of the later post-medieval sample: a problem that besets studies of human-animal relationships in this period, in part because waste management and the recycling of animal bodies was more effective in this period, but also because of problems of residuality and the low perceived value of later post-medieval faunal remains. ${ }^{67}$ Alternatively, it could reflect the fact that these kinds of horses were less likely to be deposited within the City of London. Certainly, the City would have been awash with unspecialized, but hardy coach, pack and road horses. Only with more zooarchaeological data from reliably dated deposits will the answer become clear.

\section{CONCLUSION}

The trajectory for size change in horses was different from other livestock, connected to their association with the aristocracy and their status as a non-food animal. Whilst cattle, sheep/goats, pigs and chickens were increasing in size in London in the later 14th and 15 th century, ${ }^{68}$ there was a sharp decline in the size of horses, probably connected to aristocratic disinvestment in horse breeding in the face of declining income. A major increase in the size of horses occurred in London in the 16th century, which may confirm the success of a sustained, legislated programme of "positive breeding, 69 encouraging the selection of larger phenotypes, and through hybridization with 'exotic' bloodlines, primarily for military use. There was no innovation in practice - the knowledge that stature was primarily an inherited characteristic was understood by legislators - what was innovative was the enforcement of breeding practice through a sustained and seemingly successful programme of regulation. Further increases in horse size in the 17th century reflect continuing efforts to improve native stock through importation of foreign horses and better upkeep, to meet growing demand for heavier/larger horses in agriculture, trade, industry, sport and as markers of status. The lack of data for the 18th and 19th centuries hampers attempts to identify the development of the thoroughbred and the diversification of horse breeds.

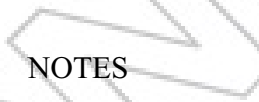

${ }^{1}$ Albarella \& Davis 1996; Armitage 1980; Davis 1997; Davis \& Beckett 1999; Holmes 2014; Thomas 2005; Thomas, Holmes \& Morris 2013.

2 e.g. Clark 1990, 20; Cowie \& Pipe 1999; Velten 2013, 44.

3 e.g. MacGregor 2012, 23; Thomas \& Locock 2000; Wilson \& Edwards 1993.

4 e.g. Cowie \& Pipe 1999; Serjeantson, Waldron \& Bracegirdle 1992; Thomas \& Locock 2000.

5 e.g. Albarella \& Davis 1996; Armitage 1980; Davis 1997; Davis \& Beckett 1999; Holmes 2014; Thomas 2005; Thomas, Holmes \& Morris 2013.

6 e.g. Thomas 2008.

7 Turvey (2005) estimates that c. 11000 horses were present in London and Westminster at the beginning of the 19th century, reaching 70,000 by the mid $1860 \mathrm{~s}$ and at least 200,000 by the end of the century.

${ }^{8}$ Clark 1990, 3.

${ }^{9}$ The earliest record for a horse fair at Smithfield dates to 1174: William Fitzstephen, a clerk to Archbishop Thomas Becket, described the site as 'a smooth field where every Friday there is a celebrated rendezvous of fine horses to be sold' (AlmerothWilliams 2011, 73).

${ }^{10}$ Von Den Driesch 1976.

${ }^{11}$ Thomas, Holmes \& Morris 2013.

12 Davis 2000; Popkin et al. 2012.

13 von Den-Driesch 1976.

${ }^{14}$ Following Kiesewalter 1888.

${ }^{15}$ Albarella 2002; Meadow 1999; Simpson, Roe \& Lewontin 1960.

${ }^{16}$ Gordon 2015; this specimen is curated by Cheshire West and Chester Council.

${ }^{17}$ Johnstone 2004.

18 Sponenberg 2003.

${ }^{19}$ Brooks et al. 2010.

${ }^{20}$ Baxter 1996; Clark 1990, 28-9; Cowie \& Pipe 1999; Edwards 1988, 24; 2007, 5; Serjeantson, Waldron \& Bracegirdle 1992. 
${ }^{21}$ Brooks et al. 2010, 163.

${ }^{22}$ MacGregor 2012, 27.

${ }^{23}$ Davis 1989.

${ }^{24}$ Clark 1990, xiii.

${ }^{25}$ Gladitz 1997, 158.

${ }^{26}$ Clark 1990, 97.

${ }^{27}$ MacGregor 2012, 30.

${ }^{28}$ Clark 1990, 97.

${ }^{29}$ e.g. Langdon 1986.

${ }^{30}$ Thomas, Holmes \& Morris 2013.

${ }^{31}$ Gladitz 1997, 147.

${ }^{32}$ Hodgett 2006, 206.

${ }^{33}$ Rackham 1986, 88

${ }^{34}$ Hamilton \& Thomas 2012.

${ }^{35}$ Davis $1989,44-5$.

${ }^{36}$ MacGregor 2012, 40.

${ }^{37}$ Edwards 1986, 16.

${ }^{38}$ Davis $1989,87$.

${ }^{39}$ Hyland 1999, 11.

${ }^{40}$ Gladitz 1997, 152.

${ }^{41}$ Davis 1989, 43-4; Stone 2005, 114.

${ }^{42}$ MacGregor 1999, 66.

${ }^{43}$ Cited in MacGregor 1999, 67.

${ }^{44}$ Thirsk 1978, 10-11.

${ }^{45}$ Thirsk 1978, 12.

${ }^{46}$ MacGregor 1999, 2012, 45-8; Dent \& Machin Goodall 1988, 139-42; Thirsk 1978, 12-13.

${ }^{47}$ MacGregor 1999, 68-9.

${ }^{48}$ Davis 1989, 85-91; Hewitt 1983， 25-6;

MacGregor 2012, 40-1.

${ }^{49}$ MacGregor 1999, 69.

${ }^{50}$ Russell 1986, 64-5.

${ }^{51}$ Thirsk 1978, 15.

${ }^{52}$ MacGregor 2012, 47.

${ }^{53}$ MacGregor 2012, 47.

${ }^{54}$ Thirsk 1978, 16.

${ }^{55}$ Edwards 1979; 1988, 2; 2007; Russell 1986, 58-9;

Thirsk 1978, 5-7, 22.

${ }^{56}$ fuset 1937, 212-13.

${ }^{57}$ Davis 1989, 69.

${ }^{58}$ Thirsk 1978, 6.

${ }^{59}$ MacGregor 1999, 73.

${ }^{60}$ Edwards 2007, 7.

${ }^{61}$ Edwards 1988, 21.

${ }^{62}$ Cited in Edwards 1988, 35.

${ }^{63}$ Velten 2013, 346

${ }^{64}$ Edwards 1988, 2007; Russell, 1986.

${ }^{65}$ Curth 2013; Davis 1989, 110-19; MacGregor

2012, 48-50; Thirsk 1978, 16-21.

66 r d...r. rds 2007; Russell 1986, 93-121.

67 2002; Thomas 2009; Thomas \& Fothergill 2014.

68 nuvias, Holmes \& Morris 2013.

${ }^{69}$ After Russell 1986, 14-22.

\section{ACKNOWLEDGEMENTS}

We gratefully acknowledge the City of London Archaeological Trust for funding this research and

Museum of London Archaeology (MOLA) for granting permission to use their data. Special thanks must go to David Bowsher, Natasha Powers, Alan Pipe and all the zooarchaeologists of MOLA past and present who recorded the data utilized. Thanks also to Rebecca Gordon for supplying the data of an 18th-century horse from London. We are grateful to Alison Foster and Rathel Small-for commenting on an earlier draft of this paper.

\section{BIBLIOGRAPHY}

Albarella, U. 2002, "Size matters": how and why biometry is still important in zooarchaeology', in Dobney \& O'Connor 2002, 51-62.

Albarella, U. \& Davis, S. 1996, Mammals and birds from Launceston Castle, Cornwall: decline in status and the rise of agriculture', Circaea 12, 1-156.

Almeroth-Williams, T. 2011, The story of Smithfield market, The London Journal: a Review of Metropolitan Society Past and Present 36, 72-76.

Armitage, P.L. 1980, 'A preliminary description of British cattle from the late 12 th to the early 16 th $\longrightarrow$ tury', Ark 7, 405-13.

- I. 1996, 'Medieval and early post-medieval horse bones from Market Harborough, Leicestershire, England, U.K.', Circaea 11, 65-79.

Becker, C., Manhart, H., Peters, J. \& Schibler, J. 1999, Historia Animalium ex Ossibus. Festschrift für Angela von den Driesch, Leidorf: Rahden/Westf.

Brooks, S.A., Makvandi-Nejad, S., Chu, E., Allen, J.J., Streeter, C., Gu, E., McCleery, B., Murphy, B.A., Bellone, R. \& Sutter, N.B. 2010, 'Morphological variation in the horse: defining complex traits of body size and shape', Animal Genetics 41, 159-65.

Clark, J. (ed.) 1990, The Medieval Horse and its Equipment c. 1150-c.1450, London: Boydell Press.

Cowie, R. \& Pipe, A. 1999, 'A late medieval and Tudor horse burial ground: excavations at Elverton Street, Westminster', Archaeol. J. 155, 226-51.

Curth, L.H. 2013, 'A Plaine and Easie Waie to Remedie a Horse': equine medicine in early modern England, Leiden: Brill.

Davis, R.H.C. 1989, The Medieval Warhorse. Origin, Development and Redevelopment, London: Thames and Hudson.

Davis, S.J.M. 1997, 'The agricultural revolution in England: some zooarchaeological evidence', Anthropozoologica 25/26, 413-28.

Davis, S. 2000, 'The effect of castration and age on the development of the Shetland sheep skeleton and a metric comparison between bones', J. Archaeol. Sci. 27, 373-90.

Davis, S.J.M. \& Beckett, J.V. 1999, 'Animal husbandry and agricultural improvement: the archaeological evidence from animal bones and teeth', Rural Hist.10, 1-17. 
Dent, A. \& Machin Goodall, D. 1988, A History of British Native Ponies, London: J.A. Allen.

Dobney, K. \& O'Connor, T.P. 2002, Festschrift for Don Brothwell, Oxford: Oxbow Books.

Driesch, A. von den 1976, A Guide to the Measurement of Animal Bones from Archaeological Sites, Cambridge, MA: Harvard University Press.

Edwards, P.R. 1979, 'The horse trade of the midlands in the seventeenth century', Agri. Hist. Rev. 27, -100 . rds, P.R. 2007, Horse and Man in Early Modern England, London: Hambledon Continuum.

Fussell, G.E. 1937, 'Animal husbandry in eighteenth century England'. Agri. Hist.11, 189-214.

Gladitz, C. 1997, Horse Breeding in the Medieval World, Portland: Four Courts Press.

Gordon, R.L. 2015, 'Feeding the City: Zooarchaeological Perspectives on Urban Provisioning in Post-Medieval England (AD 1500-1900)', University of Leicester PhD thesis.

Hamilton, J. \& Thomas, R. 2012, 'Pannage, pulses and pigs: isotopic and zooarchaeological evidence for changing pig management practices in 14th century England', J. Medieval Arch. 56, 234-59.

Hardy, A. 2002. 'Pioneers in the Victorian provinces: veterinarians, public health and the urban animal economy', Urban Hist. 29, 372-86.

Hewitt, H.J. 1983, The Horse in Medieval England, London: J.A. Allen.

Hodgett, G. 2006, A Social and Economic History of Medieval Europe, Abingdon: Routledge.

Holmes, M. 2014, 'Does size matter? Changes in the size and shape of animals throughout the English Saxon period (AD 450-1066)', J. Archaeol. Sci. 43, $\longrightarrow-90$. Id, A. 1999, The Horse in the Middle Ages, Stroud: Sutton.

Johnstone, C. 2004, 'An Osteometric Study of Equids in the Roman World', University of York PhD th $\sim$ :

Kies , L. 1888, 'Skelettmessungen am Pferdeals Bunugzur Theoretischen Grundlage der Beurteilungslehre des Pferdes', Leipzig University $\mathrm{PhD}$ thesis.

Langdon, J. 1986, Horses, Oxen and Technological Innovation, Cambridge: University Press.

MacGregor, A. 1999, 'Strategies for improving English horses in the sixteenth and seventeenth centuries', Anthropozoologica 29, 65-74.

MacGregor, A. 2012, Animal Encounters: Human and Animal Interaction in Britain from the Norman Conquest to World War One, London: Reaktion Books.

Meadow, R., 1999, 'The use of size index scaling techniques for research on archaeozoological collections from the Middle East', in Becker et al. 1999, 285-300.
Olsen, S.L. 2003, Horses through Time, Pittsburgh: Roberts Rinehart Publishers for Carnegie Museum of Natural History.

Popkin, P.R.W., Baker, P., Worley, F., Payne, S. \& Hammon, A. 2012,'The sheep project (1): determining skeletal growth, timing of epiphyseal fusion and morphometric variation in unimproved Shetland sheep of known age, sex, castration status and nutrition', J. Archaeol. Sci. 39, 1775-92.

Rackham, O. 1986, The History of the Countryside: the Classic History of Britain's Landscape, Flora and Fauna, London: Dent.

Russell, N. 1986, Like Engend'ring Like: Heredity and Animal Breeding in Early Modern England, Cambridge: University Press.

Serjeantson, D., Waldron, T. \& Bracegirdle, M. 1992, 'Medieval horses from Kingston-upon-Thames', London Archaeologist 7, 9-13.

Simpson, G.G., Roe, A. \& Lewontin, R.C. 1960, Quantitative Zoology, New York: Harcourt Brace.

Sponenherg, D.P. 2003, 'Of horse breeds', in Olsen $2 \bigcirc 53-74$.

Stall , S. \& Thomas, R. 2008, Feeding the Roman Army: the Archaeology of Production and Supply in NW Europe, Oxford: Oxbow.

Stone, D. 2005, Decision Making in Medieval Agriculture, Oxford: University Press.

Thirsk, J. 1978, Horses in Early Modern England: for Service, for Pleasure, for Power, Reading: University of Reading.

Thomas, R. 2005, 'Zooarchaeology, improvement and the British agricultural revolution', Int. J. Hist. Archaeol. 9, 71-88.

Thomas, R. 2008, 'Supply-chain networks and the Roman invasion of Britain: a case study from Alchester, Oxfordshire', in Stallibrass \& Thomas 8, 31-51.

s, R. \& Fothergill, B.T. 2014a, 'Animals, and their bones, in the "modern" world: a multi-scalar zooarchaeology', in Thomas \& Fothergill 2014b, 11-18.

Thomas, R. \& Fothergill, B. (eds) 2014b, Animals, and their bones, in the "modern" world (AD 1750-1900), Anthropozoologica $49 \rightleftarrows 8$ \%

Thomas, R. \& Locock, M. 2000, 'Fo the dogs? The consumption of horseflesh at Dudley Castlein the eighteenth century', Envir. Archaeol. 5, 83-92.

Thomas, R., Holmes, M. \& Morris, J. 2013, "'So bigge as bigge may be": tracking size and shape change in domestic livestock in London (AD 1220-1900)', J. Archaeol. Sci. 40, 3309-25.

Turvey, R. 2005. 'Horse traction in Victorian London', J. Transp. Hist. 26, 38-59.

Velten, H. 2013, Beastly London, London: Reaktion Books.

Wilson, B. \& Edwards, P. 1993, 'Butchery of horse and $\operatorname{dog}$ at Witney Palace, Oxfordshire, and the knackering and feeding of meat to hounds during the post-medieval period', Post-Medieval Archaeol. 27, 43-56. 
RÉSUMÉ

'The brede of good \& strong Horsis': indices zooarchéologiques de changement de taille des chevaux au début de l'époque moderne à Londres

Des analyses ont été réalisées à partir des près de 200 mesures d'ossements de chevaux provenant de 38 sites fouillés à travers la ville de Londres et datant de la période 1220-1900 ap. JC. Les résultats ont permis d'identifier trois phases principales dans le changement de taille: une réduction de la taille au milieu du XIVe-XVe siècle, et des augmentations de la taille d'abord au milieu du XVe-XVIe siècle, puis au XVIIe siècle. Le déclin de la taille témoigne de la perturbation de la reproduction chevaline à la suite de la Peste Noire, tandis que l'augmentation reflète des tentatives intentionnelles d'augmenter la taille des chevaux en Angleterre par une combinaison de reproduction régulée et d'importation de nouvelles lignées.

\section{ZUSAMMENFASSUNG}

'Die Zucht guter \& starker Horsis': zooarchäologische Beweise für die Größenänderung des Pferdes im früh-modernen London

Messungen der fast 200 Pferdeknochen, ausgegraben auf 38 Grabungsstellen in der City of London aus der Zeit AD 1220-1900, wurden analysiert. Ergebnisse identifizierten drei Hauptphasen der Größenänderung: eine Verkleinerung in der Mitte des 14.-15. Jahrhundert, während die Größe sich erhöhte in der Mitte des15. bis 16. Jahrhunderts und im 17. Jahrhundert. Der Rückgang der Größe zeugt von dem Einfluss auf die Pferdezucht im Zuge des Schwarzen Todes, während die Anstiege gezielter Versuche widerspiegeln, wie die Größe der Pferde in England durch eine Kombination von geregelter Zucht und Einfuhr neuer Blutlinien beeinflusst wurden.

\section{RIASSUNTO}

'Allevare cavalli buoni e forti': dati zoo-archeologici sul cambiamento di statura dei cavalli nella Londra della prima età moderna

Sono stati analizzati i dati sulle misurazioni di circa 200 ossi di cavallo provenienti da 38 diversi siti nell'area metropolitana di Londra e databili fra il 1220 e il 1900. I risultati hanno messo in evidenza tre principali fasi nel cambiamento di statura degli animali: una riduzione fra la metà del XIV e il XV secolo, seguita da due incrementi, di cui il primo fra la metà del XV e il XVI secolo e il successivo nel XVII secolo. La prima fase testimonia una discontinuità nell'allevamento dei cavalli come conseguenza della peste nera, mentre gli incrementi nella statura dei cavalli inglesi riflettono tentativi deliberati in quella direzione, ottenuti combinando l'allevamento controllato con l'importazione di nuove linee di sangue.

\section{RESUMEN}

'La cría de caballos buenos y fuertes': evidencia zooarqueológica en el cambio de tamaño en caballos del Londres temprano moderno

Este artículo presenta los resultados de la medición de casi 200 huesos de caballo procedentes de 38 excavaciones en la ciudad de Londres de entre 1220 y 1900 d.C. Los resultados identificaron tres fases principales en el cambio del tamaño de los caballos: una reducción a mediados del siglo $\mathrm{XIV}-\mathrm{XV}$, un aumento de tamaño entre mediados del siglo XV-XVI, y otro en el siglo XVII. La disminución del tamaño refleja la interrupción de la cría de caballos tras la peste negra, mientras que los aumentos son intentos conscientes de aumentar el tamaño de los caballos en Inglaterra mediante una combinación de cría regulada y la importación de nuevas líneas de sangre. 